\title{
CONFLICTING INSTITUTIONS IN PLANNING INFRASTRUCTURAL CORRIDORS: A CASE STUDY OF INFRASTRUCTURAL CORRIDOR NIŠ - BULGARIAN BORDER
}

\author{
Milica Maksić ${ }^{1} \&$ Milica Dobričić ${ }^{2}$ \\ ${ }^{1}$ Institute of Urban Planning City of Niš, Serbia \\ Serbia, 18000 Niš, 7. July st. 6, e-mail:mmaxic@gmail.com \\ ${ }^{2}$ Ministry of Construction, Transport and Infrastructure, Serbia \\ Serbia, 11000 Belgrade, Kralja Milutina st.10a; e-mail: milica.dobricic@mgsi.gov.rs
}

\begin{abstract}
Planning crucial infrastructural corridors is a fragile question, especially from the aspect of conflicting interests between different interest groups. This paper, through the analysis of process of elaboration of Spatial plan for the area of infrastructural corridor Niš-Bulgarian border (changes and amendments), points to complex institutional and policy environment in decision-making on this type of development. Infrastructural corridor Niš-Bulgarian border is of strategic European and national importance which units functions of transport (road and railway) and infrastructure (gas pipeline and product line). On its way to Bulgarian border it connects 4 units of local self-government: territories of cities of Niš and Pirot and the municipalities of Bela Palanka and Dimitrovgrad. Through the analysis of attitudes of different institutions, especially the public sector one at the public review meeting, the paper researches present conflicts in planning infrastructure corridors in Serbia and the way of their overcoming.
\end{abstract}

Keywords: institutions, conflicts, infrastructural corridor, planning.

\section{INTRODUCTION}

Travelling route Niš - Bulgarian border $(E-80)$ has very important traffic function in the Republic of Serbia (national road of IA order - A4), as well as in the E-roads of Central and Southeast Europe. It represents the branch of the main road (national road of IA order - A1) (M-1), which is directed towards Bulgaria and Turkey, respectively the countries of the Near and Middle East, and the traffic and strategic coincides with the direction of trans-European (TEM) road and part "C" of the Pan-European Multimodal Corridor "X". As an integral part of the optimal road connection between the European and Asian road network, it has great importance in communication of Europe with the Middle East through the territory of the Republic of Serbia and in connection the countries of the Western European and Alpine areas with the countries of Southeast Europe and Asia.

Railways in the corridor "X" will connect the Republic of Serbia with all parts of Europe, as well as with the Near and Far East. The corridors of the "X" corridor, which include the E-70 railroad, will enable regulation of rail transport and connecting large cities of Europe with the cities of the Republic of Serbia, high-speed dual-track high-speed buses (passenger and freight) and combined transport with projected speeds of $160 \mathrm{~km}$ and where possible, at speeds of up to $220 \mathrm{~km}$.

Based on the plan for the development of the European rail network and the development of railway transport in the Republic of Serbia, it has been established that high performance lines represent an upgrade to the standard of double speed rail system. These railroads fit into Europe's high-speed rail network. 


\section{ARTTIE $Y$}

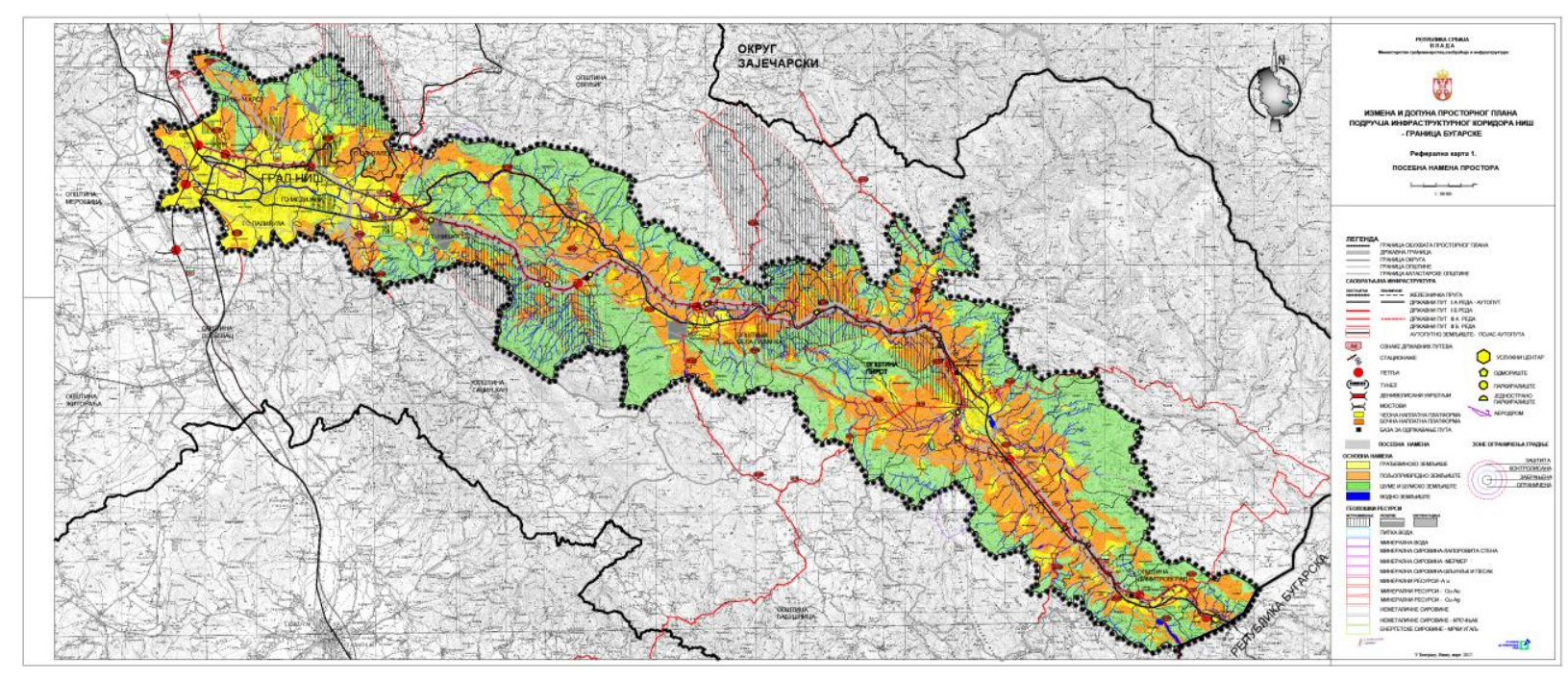

Figure 1. Referral Map 1: Spatial purpose of area [1]

The basic Spatial plan for the area of infrastructural corridor Niš-Bulgarian, which was made for E-80 corridor from the year 2009, had four variants. The project documentation did not follow planning solutions in some segments, so the amendments of plan were initiated in the year 2016 to cover these changes.

This Spatial plan includes parts of the territories of the cities of Niš and Pirot and the municipalities of Bela Palanka and Dimitrovgrad. It includes in particular:

1) E-80 highway corridor, section Niš - Bulgarian border, of total length of $105,4 \mathrm{~km}$ and width from $200 \mathrm{~m}$ to $700 \mathrm{~m} \mathrm{(100} \mathrm{m}$ and $350 \mathrm{~m}$ respectively from the axis of the corridor of the highway) includes the route with protective belts (direct protective belt - with trace, loops, denivelised crossings and accompanying functional contents of road traffic, facilities for traffic users, protective greenery, etc., and wider zone of protection);

2) existing and planned corridors of other mainstream infrastructure systems that are within the scope of the planning area, such as railway lines, gas pipelines, transmission lines, optical cables and water infrastructure [1].

The total surface area of the Spatial plan covers of about $1150.65 \mathrm{~km}^{2}$. In the preparation of the amendments and supplements of the spatial plan, cooperation was established with Public Enterprise "Roads of Serbia" (JP „Putevi Srbije), "Corridors of Serbia doo" (Koridori Srbije d.o.o), " Serbian Railway Infrastructure" (Infrastruktura železnice Srbije) and Ministry of Construction, Transport and Infrastructure (Ministarstvo građevinarstva, saobraćaja $i$ infrastrukture) which provided the necessary documentation for plan elaboration (adopted or revised conceptual or main projects, acquired obligations and requirements-initiatives for accompanying contents on the corridor line), as well as the opinions of competent ministries. 


\section{ARTTIE $Y$}

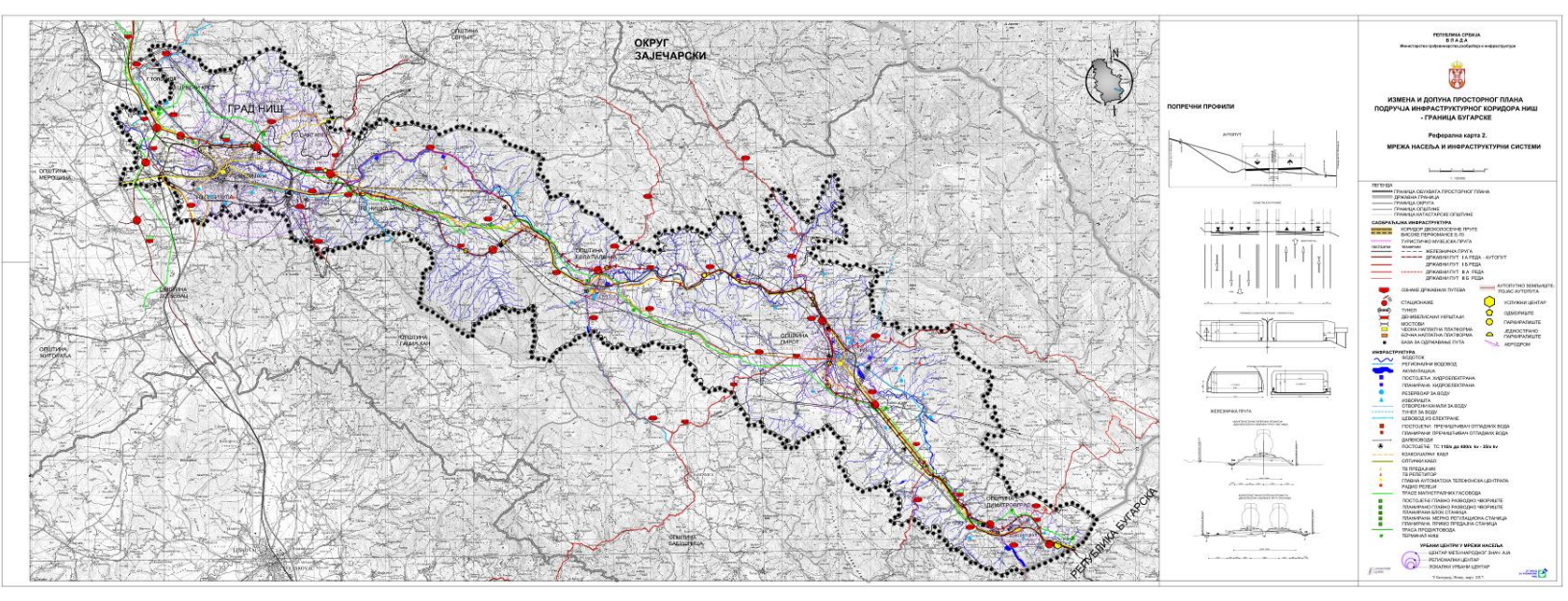

Figure 2. Referral Map 2: Network of Settlements and Infrastructure Systems [1]

\section{ANALYSIS OF DECISION-MAKING PROCESS}

During spatial plan elaboration, the fundamental institutional conflict was expressed in the opposing views of the enterprise "Serbian railway infrastructure AD" (Infrastruktura železnice Srbije $A D$ ), and units of local self-government in the scope of the plan.

Plans of "Serbian railway infrastructure AD" (National program for public railway infrastructure in the period 2016-2020, Plan for the development of railway, road, water, air and intermodal transport in the Republic of Serbia from 2015 to 2020, Long-term and midterm plan of the business development strategy "Infrastructure of the Serbian Railways" for the period 2017-2027) predicted reconstruction, modernization and electrification of the existing single-rail railway Niš - Dimitrovgrad - the border of Bulgaria. All units of local selfgovernment within the scope of the plan have opposed plans for the electrification of railways that pass through the cores of urban areas of their headquarters.

During the public review of the Spatial plan draft, 46 complaints were received and they were registrated in the Report on the public insight into the draft of Amendments and supplements of the Spatial plan of the area of infrastructure corridor Niš - Bulgarian border (Izveštaj o obavljenom javnom uvidu u nacrt Izmena $i$ dopuna prostornog plana područja infrastrukturnog koridora Niš - granica Bugarske) [2]. The public authority - Commission of the Ministry of Construction, Traffic and Infrastructure made a report containing the information on the performed public insight, with all objections and decisions on each objection, about the performed public insight into the planning document. This is the body at the national level, formed from the licensed experts by the Minister for the expert control of regional spatial plans and spatial plans of the special purpose areas.

During the public review, City of Pirot had a request that planned double-track railroad for the high speed velocity E-70s, should be moved out of the urban core of the populated city of Pirot. They consider this as an absolutely unacceptable solution from the aspect of traffic safety, since the railway passes through the urban core of the populated town of Pirot and the densely populated suburbs Radin Do, Prčevac and Đeram, and it crosses the city roads on 7 connections between urban and suburban settlements, with a very active population and large number of children going to school. 


\section{ARTTIE $Y$}

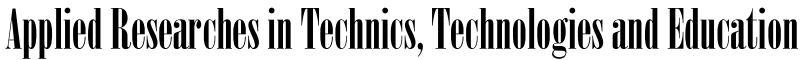

Journal of the Faculty of Technics and Technologies, Trakia University https://sites.google.com/a/trakia-uni.bg/artte/

For years, the City of Pirot addressed the Serbian Railway Infrastructure with the requirements for better provision of road crossings over the railway Niš - Dimitrovgrad due to the high number of traffic accidents. City of Pirot considers that the additional increase in the speed and intensity of rail transport will be extremely unfavourable for the safety of all participants in the traffic.

The remark was partially accepted by the Commission. It is accepted in the part referring to the necessary increase in security that is covered by the technical solutions specified in the plan. No proposal to move the railway line is accepted. It is underlined that while referring to the concept of high speed construction, it should be emphasized in all parts of the text of the plan that this refers to a long-term vision. The high speed corridor should not be included in the graphic part of the plan.

Municipality of Dimitrovgrad had similar request. The Spatial plan draft defined on page 22 of section 1.2. The position of the E-70 railroad corridor, that the reconstruction of the existing mainline single-track railway no. 5: Niš-Dimitrovgrad-state border - Dragoman is planned and that by 2020, another rail will be built, parallel to the existing one (according to the graphic), how conditions for the operation of high-performance dual-track electrified railroads would be created.

Municipality of Dimitrovgrad opposed to planning solutions for building another rail, parallel to the existing one (according to the graphic), for creating conditions for the operation of highperformance dual-track electrified railroads. They believe that the introduction of another track through the city core is inadmissible. Even now with one track that divides Dimitrovgrad along the length (with 3 road crossings in only 1000m), Dimitrovgrad has big problems with road traffic, with the noise and inability to make a space in the central part of the city through which the railway passes (crossings with a large number of streets, the impossibility of a proper traffic solution through the city). According to municipality, construction of another track through the city core is unfeasible because there is not enough space, many objects should be destroyed, the two-track railway with electrification would take a significant part of center of Dimitrovgrad, because of the speed of trains from $160 \mathrm{kt}$ to $220 \mathrm{kt}$ quality of life in the city will be greatly disturbed.

The municipality suggested that planned second track should be separated from the existing mainline single-track railway and be led by another route outside the city core, which was foreseen in the original plan of 2003 - a 3,8 km tunnel through the Mrtvina hill, on the south of the settlement. Another option, according to Municipality of Dimitrovgrad and experts opinion from the area that have been consulted, is that the railway line (dual-track) should be buried, through the city core, under the present level.

The answer of Planning Commission was similar as in the case of City of Pirot. The remark was partially accepted by the Commission. The part that relates to high speed velocity railways was not accepted.

Municipality of Dimitrovgrad had one more request for planning the loop of Dimitrovgrad as one-way loop to allow the connection of Dimitrovgrad towards Niš direction and vice versa. The explanation was that a good technical solution for the connection of Dimitrovgrad with the highway to the west of the settlement was not provided ("Dimitrovgrad-west" loop), because vehicles from the Bulgarian direction cannot connect to that loop and cannot make a connection with the city and work zone "Beleš" near this loop. The municipality believes that the inadequate access to Dimitrovgrad from the highway will be reflected in the quality of life in the city, because the trucks will have to pass through the city core and the residential area, what can have unimaginable consequences for the safety of citizens and pollution of the environment. This remark was accepted by the Planning Commission.

Municipality of Bela Palanka also opposed planning solutions for high-performance railways through the core of Bela Palanka. The municipality envisaged that by the proposed Spatial

IRTIIE Vol. 5, No. 4, 2017 ISSN 1314-8788 (print), ISSN 1314-8796 (online), doi: 10.15547/artte.2017.04.003 


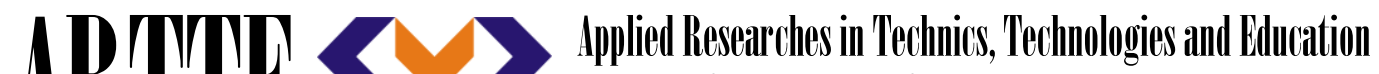 Journal of the Faculty of Technics and Technologies, Trakia University https://sites.google.com/a/trakia-uni.bg/artte/}

plan draft high-performance double-rail high-speed railway will divide Bela Palanka into two parts, and this will make the communication of the city center with the largest and youngest settlement in Bela Palanka more difficult. Therefore, they considered that the removal of the railway line outside Bela Palanka should be carried out, preferably in the area north of Bela Palanka, where the current bypass road is located. Planning Commission did not accept this remark.

\section{CONCLUSION}

Considering the requirements of local self-government units from the summit of summarizing the public insight, as well as the position of the Planning Commission, we can conclude the following. In planning railway infrastructure, in the institutional confrontation between the national enterprise Serbian Railways Company and local self-governments, the position of Serbian Railways Company is significantly stronger. The institutional body on the national level - the Commission of the Ministry of Construction, Traffic and Infrastructure for the professional control of regional spatial plans and spatial plans of the special purpose areas, through the procedure of public review, tried to overcome the differences between the actors. Municipalities in the area of Spatial plan didn't have enough capacity and national level support to change plans of "Railway Infrastructure of Serbia". Whether these plans will be realized this way, it remains to be seen in future period.

\section{REFERENCES}

[1] JP Zavod za urbanizam Niš: Izmena i dopuna prostornog plana područja infrastrukturnog koridora Niš - granica Bugarske / Institute of urban planning city of Niš: Amendments and supplements of the Spatial plan of the area of the infrastructure corridor Niš Bulgarian border.

[2] Ministarstvo građevinarstva, saobraćaja i infrastrukture: Izveštaj o obavljenom javnom uvidu u nacrt Izmena i dopuna prostornog plana područja infrastrukturnog koridora Niš granica Bugarske / Ministry of Civil Engineering, Transport and Infrastructure: Report on the public insight into the draft of Amendments and supplements of the Spatial plan of the area of the infrastructure corridor Niš - Bulgarian border. 